\title{
Virtual water and food security in Tunisian semi-arid region
}

\author{
Lamia Lajili-Ghezal, Talel Stambouli", Marwa Weslati, Asma Souissi
}

ESA Mograne, 1121 Mograne, Tunisia

Email address:

tstambouli@cita-aragon.es (T. Stambouli)

\section{To cite this article:}

Lamia Lajili-Ghezal, Talel Stambouli, Marwa Weslati, Asma Souissi. Virtual Water and Food Security in Tunisian Semi-Arid Region. Agriculture, Forestry and Fisheries. Vol. 3, No. 5, 2014, pp. 341-345. doi: 10.11648/j.aff.20140305.12

\begin{abstract}
To confront water scarcity and support food security, the concept of virtual water is used. As defined by Allan (1997) virtual water is "the water embedded in key water-intensive commodities such as wheat" or "the water required for the production of commodities". The importance of this concept is related to its potential contribution for saving water, especially in water short regions like Tunisia. This research study tries to evaluate the strategic importance of polluted or gray water, which is a component of virtual water. Reduction of virtual water for strategic agricultural products can be obtained by the gray water reduction. The latter is defined as "water required diluting polluted water to reach the normalized quality, different with countries". Water pollution is especially related to use of chemical products (fertilizers, pesticides, etc.) for some crops like vegetables. Besides having a lower opportunity cost, the use of green water for crop production has generally less negative environmental externalities than the use of blue water (irrigation with water abstracted from ground or surface water systems). Tunisia exports some crops and gray water volumes in exports have rarely been estimated. Thus, estimation of gray water plays a role in ensuring water and water-dependent food security and avoiding further potential damage to the water environments in both importing and exporting countries. In this context, Tunisian semi-arid region is chosen because the presence of a long period of dry and shiny, occurring after a cold and rainy one, useful for vegetables crops and family food security. The aim of this study is to present: Methodologies which can be used to reduce virtual water for some strategic vegetables crops in Tunisian semi-arid region, based on irrigation techniques improvements and the control of runoff and leaching water; Resources management practices that can be used to improve family income, especially women and children and target food security.
\end{abstract}

Keywords: Virtual Water, Food Security, Water Quality Conservation, Family Income, Gender

\section{Introduction}

Agriculture has always occupied an important place in the socio-economic development in Tunisia. The agriculture expansion is heavily relied on available natural resources, especially on water. Because of its geographical location, Tunisia undergoes the influence of two climate types: the Mediterranean type in the north and the Saharan type in the south which are at the origin of space and time variability in water resources. Therefore, the annual rainfall average varies from less than $100 \mathrm{~mm}$ in the extreme south to more than $1500 \mathrm{~mm}$ in the extreme northern parts of the country. Water resources are evaluated in 2000 to 4825 million $\mathrm{m}^{3}$, with 2700 million $\mathrm{m}^{3}$ of surface water and 2,125 million $\mathrm{m}^{3}$ of ground water. Tunisia is, then, a country with relatively limited renewable water resources (SEMIDE, 2002).

That's why; taking into consideration the scarcity of water resources in the planning of agricultural policies is necessary to improve the trade balance, to ensure a level of food security, and to enhance the countryside and the environment. In this context, many countries attempt to reach new alternatives for the management and the sustainable use of water resources in particular. These new approaches have brought about a relatively new idea called virtual water (VW) which tries to give an explanation to water use management (Velázquez, 2007).

The virtual water concept, defined by Allan (1997), as the amount of water needed to generate a product of both natural and artificial origin, this concept establish a similarity between product marketing and water trade. Virtual Water trade can alleviate, in arid countries, the problem of water scarcity, increasing imports of products with high virtual water content and so, it can allocate scarce resources to higher priority uses. 
Given the influence of water in food production, virtual water studies focus generally on food products. At a global scale, the influence of these product's markets with water management was not seen. Influence has appreciated only by analyzing water-scarce countries at global scale, but at the detail level, should be increased, as most studies consider a country as a single geographical point, leading to considerable inaccuracies. For this reason, we consider the value of exploring virtual water strategy at smaller scales such as an irrigated area. Besides having a lower opportunity cost, the use of green water for the production of crops has generally less negative environmental externalities than the use of blue water (irrigation with water abstracted from ground or surface water systems). Also shinny regions are generally useful for Mediterranean crops and have less negative impact on environment.

In this context, Tunisian semi-arid region is chosen because of presence of dry and shiny period, occurring after a cold and rainy one, useful for vegetables crops and family food security.

Objectives of this work are:

a) Estimation of virtual water balance of strategic irrigated crops (vegetables) in semi-arid areas of Tunisia to determine their influence on the water resources management and to establish patterns for improving it ;

b) Study of resources management practices that can be used to improve family income, especially women and children and target food security.

Based on farmer's surveys, crop and meteorological data, irrigation management and regional statistics.

\section{Material and Methods}

To estimate the virtual water for different crops, several models were used with the objective to determine the water consumed by the plant. In this study, net irrigation requirements for studied crops and regions were computed following the FAO56 method (Allen et al, 1998) from meteorological data available.

Crop evapotranspiration (ETM, equation 1) was estimated from reference evapotranspiration $\left(\mathrm{ET}_{0}\right)$ and the appropriate crop coefficients $\left(\mathrm{K}_{\mathrm{c}}\right)$.

$$
E T M=K_{c} E T_{0}
$$

Reference evapotranspiration $\left(\mathrm{ET}_{0}\right)$ was computed using the Penman-Monteith method (Smith 1993). The crop coefficients values at the initial, medium and end of the crop stages $\left(K_{c}\right.$ ini, $K_{c}$ med and $K_{c}$ end), the general lengths $(L)$ for the different growth stages $\left(\mathrm{L}_{\text {ini }}, \mathrm{L}_{\text {dev }}, \mathrm{L}_{\text {mid }}\right.$ and $\left.\mathrm{L}_{\text {late }}\right)$ and the total growing period for the main crops. Net Irrigation requirements (NIR, equation 2) were calculated using the standard FAO procedures, as described by Allen et al. (1998). Effective precipitation (EP) was calculated using the empirical USDA method (Cuenca, 1989). Following these procedures, reference evapotranspiration $\left(\mathrm{ET}_{0}\right)$, crop coefficients $\left(\mathrm{K}_{\mathrm{c}}\right)$, crop evapotranspiration $\left(\mathrm{ET}_{\mathrm{c}}\right)$, effective precipitation (EP) and net irrigation requirements (NIR) were estimated for the main crops in the AID in 2011.

$$
N I R=\left(K_{c} E T_{0}\right)-E P
$$

Net irrigation requirements calculations are based on the soil moisture regime and the phenological stage of the crop, while keeping the other variables at the optimal production level. On this basis, we can calculate crop coefficients for a given location. It is also possible to construct the mathematical function that connects the crop water consumption to the desired crop yield.

The choice of a model depends on the objectives of the study. When the most important is the relationship between water and crop production, which is the case, FAO models (AQUACROP and CROPWAT) are frequently used. CROPWAT is the simplest, based on empirical relationships between water availability and production.

In this study, virtual water consumed by crops was calculated as green (water provided by rain) and blue (water provided by irrigation) water. The present study estimates the green and blue water footprint of 1 kilogram of vegetables produced in semi-arid area in Tunisia following the method described by Hoekstra et al. (2009).

In the study, vegetable production in the different Tunisian semi-arid regions was considered, distinguishing production throughout the year as well as between growing systems. The study focuses on the production stage, that is, the cultivation of the product, from sowing to harvest. The crop virtual water was calculated for each year distinguishing the green and blue water components.

The virtual water of vegetables (rainfed or irrigated) has been calculated distinguishing the green and blue water components Within the CROPWAT model (FAO, 2009)., the 'irrigation schedule option' was applied, which includes a dynamic soil water balance and keeps track of the soil moisture content over time. The calculations have been done using climate data from representative meteorological stations located in the major crop-producing regions, selected depending on data availability.

Low virtual water values can be obtained by use of green water and reduction of blue water, based on improve of irrigation techniques and control of runoff and leaching water. For Tunisian semi-arid region, the best seasons for this are spring and autumn.

Vegetable crops generally need a large amount of workers, which can bring agricultural income, especially for women and children and then target food security for them. To perform this, statistical and field analysis of workers (ONAGRI, 2010), for Tunisian semi-arid region, were used.

\section{Results and Discussion}

Based on the results of the research project "Virtual Water and Food Security in Tunisia: from observation to support development" (VWFST), related to virtual water in food 
security strategy in Tunisia and its implications on the economy of water resources, the following data were used:

- Spatial bioclimatic distribution (governorate), to select governorates that are located on Tunisian semiarid region;

- Estimation of gross margin of water, obtained from collected data sheets elaborated by the regional research team of the project.

\subsection{Semi-Arid Governorates}

Based on the results of the research project (VWFST), 5 governorates which are mainly located in the Tunisian semiarid region ( $>50 \%$ of the total area of the governorate), were identified: Ariana, Ben Arous, Manouba, Tunis and Zaghouan. Field investigation results, related to the latter, were used in this paper.

\subsection{Virtual Water}

Figure 1 presents the net irrigation requirements (NIR) for the studied crops and irrigated zones in semi arid area. NIR slightly increase for all studied crops from the north to the center of Tunisia, this increase is due to that central regions of the country receive less rain. Some vegetables such as pepper, pea and bean do not need irrigation in some regions and have a negative NIR, which means that virtual water consumed by these crops was only provided by the rain or green water. Cultivating these crops in these areas of the country helps minimize irrigation water consumption and thus the virtual water reduction. Summer crops such as tomato and pepper have the highest NIR from $430 \mathrm{~mm}$ in Bizerte to $600 \mathrm{~mm}$ in Monastir.

Awareness of the farmer to managing water resources is related to knowing the real crop water requirements at different stages of crop development although he manages well the irrigation scheduling. Over irrigation as infrairrigation, have a negative impact on crop productivity. Finally, the virtual water concept, contextualized in space and time can provide useful information for benchmarking, indentifying best practices and achieving a more integrated water resource management. Nevertheless, to obtain a comprehensive picture, not only the (eco) efficiency in terms of $\mathrm{m}^{3}$ /ton should be considered, but also the context-specific total cumulative virtual water.

Analysis of field investigation results for Zaghouan governorate showed that the most cultivated vegetables crops on 2013 are: Tomato, Watermelon, Potato and Artichoke.

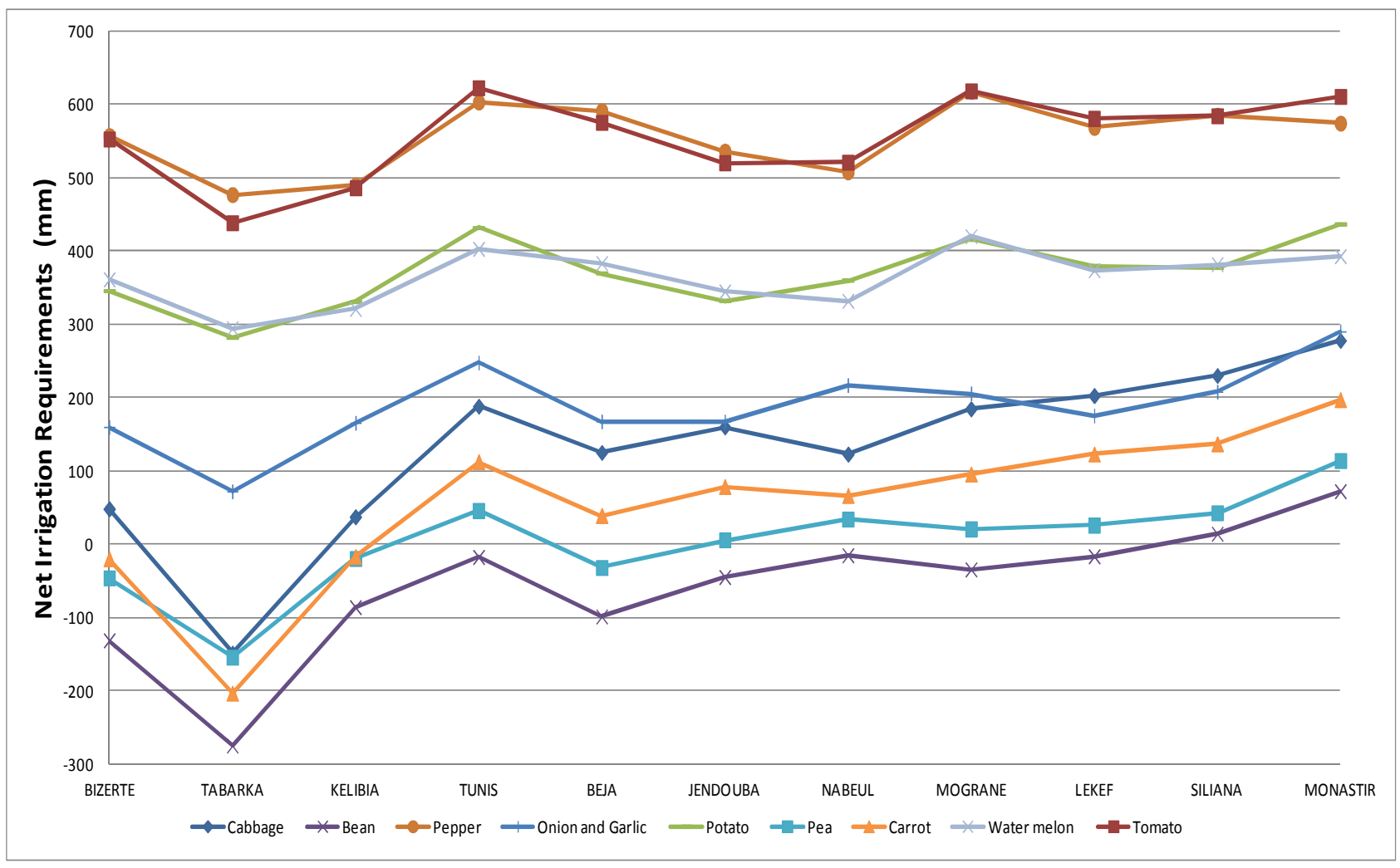

Figure 1. Net irrigation Requirements ( $\mathrm{mm}$ ) for studied vegetables in Tunisian semi arid areas.

Figure 2, represents estimation of Virtual Water $\left(\mathrm{m}^{3} / \mathrm{kg}\right)$ and Gross Margin of Water $\left(\mathrm{DT} / \mathrm{m}^{3}\right)$, for the mentioned crops. 


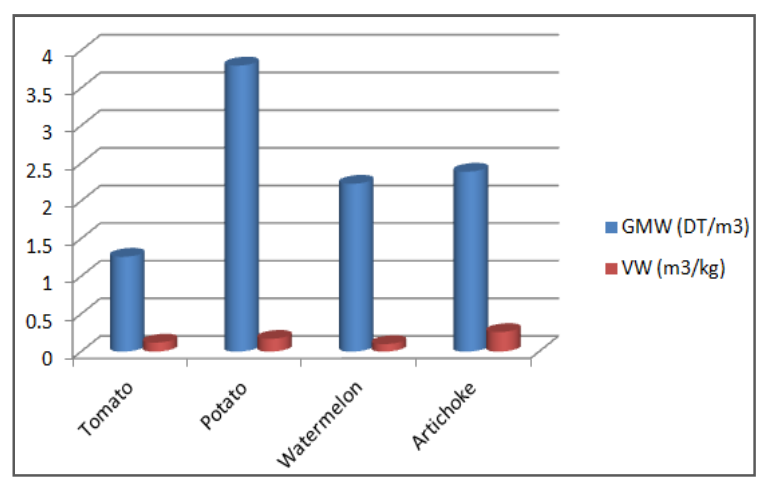

Figure 2. Variation of virtual water $\left(\mathrm{m}^{3} / \mathrm{kg}\right)$ and gross margin of water $\left(D T / \mathrm{m}^{3}\right)$ with vegetable crops for Zaghouan governorate.

\subsection{Labor}

Figure 3 showed the evolution of agricultural worker's structure.

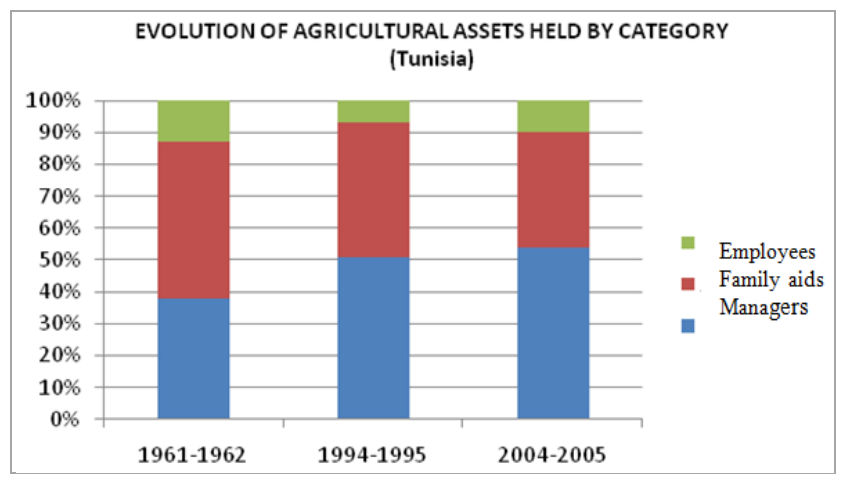

Figure 3. Evolution of Tunisian agricultural workers

Figure 3 shows increases in farm manager's percentage compared to family aids, which proves that the Tunisian agriculture has evolved into modern and productive agriculture.

Statistical data related to Tunisian agricultural and gender workers, are presented on the figures below.

Variations of gender permanent and family workers for Tunisian semi-arid governorates are showed by figures 4 and 5 respectively.

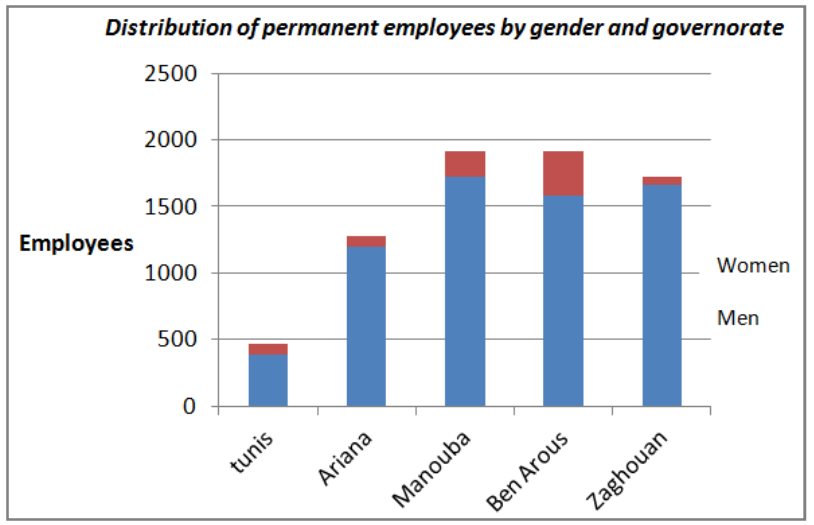

Figure 4. Variation of gender permanent workers for Tunisian semi-arid governorates

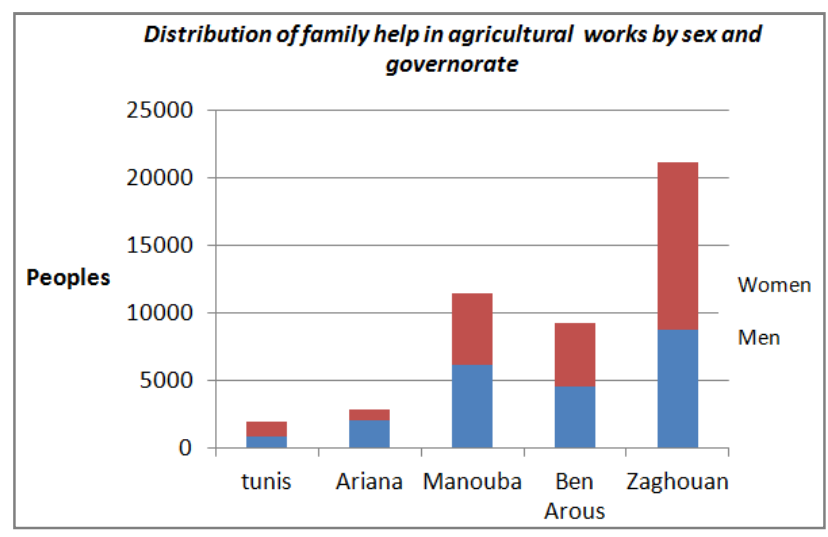

Figure 5. Variation of gender family workers for Tunisian semi-arid governorates

Variation of Tunisian permanent workers with area's farm is presented by figure 6 , while the variation of Tunisian family workers with area's farm and gender is showed by figure 7 .

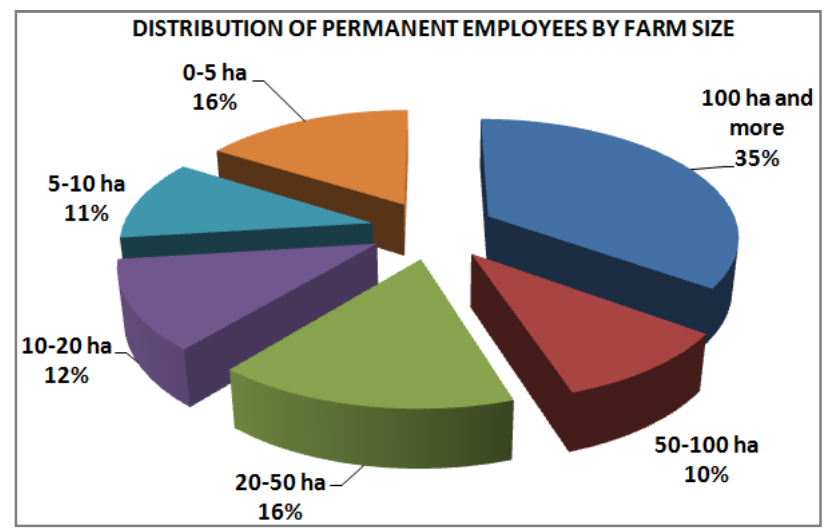

Figure 6. Variation of Tunisian permanent workers with area's farm

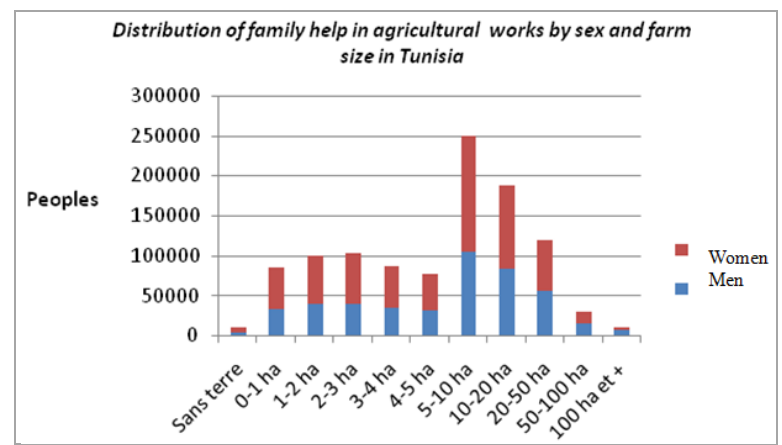

Figure 7. Variation of Tunisian family workers with area's farm

Agricultural family workers are the most important for Zaghouan governorate (Figure 5). For this governorate, field investigation for a sample of farmers showed that agricultural women workers represent $75 \%$ of the total agricultural workers. The tasks performed by women are: seedlings, planting, weeding, replacement, fertilizing, mulching and crop harvesting. Mechanical and chemical tasks are typically performed by men: plugging, mechanical and chemical weeding, fertilizer application and marketing. 


\section{Conclusion}

The use of the virtual water concept to confront water scarcity and support food security, in Tunisian semi-arid region showed that:

- Spring and autumn vegetable crops present low virtual water and are thus recommended for this region;

- vegetables are one of the most important agricultural activities in the country contributing to food security needs in water are relatively high compared to other agricultural products;

- Citrus present the high virtual water in the studied regions;

- Reduction of virtual water for these vegetables crops in Tunisian semi-arid region, can be obtained by improve of irrigation techniques and control of runoff and leaching water, using drip, localized and underground irrigations ;

- The virtual water estimation by using a model that gives enough information to perform the value of consumed water each crop and the water wasted by the farmer can help to guide agricultural policy for better water management;

- The concept of virtual water should be treated with caution in trying to both manage water resources according to speculation and ensure food security;

- It seems clear that integrated water allocation, planning and management is needed in the Tunisian semi-arid regions, considering the environmental water requirements together with the blue (surface and ground) and green virtual water, to achieve a more compatible agricultural production.

\section{Acknowledgments}

This research was funded by the IRDC of the Government of Canada through grant "Virtual water and food security in Tunisia: from observation to support development. Authors would like to thank the Regional Commission for
Agricultural Development managers and farmers for their support. We are also thankful for the comments by reviewers.

\section{References}

[1] Allan, J.A., 1997. "Virtual water": A Long Term Solution for Water Short Middle Eastern Economies? : Occasional paper, no. 3. Water Issues Study Group, School of Oriental and African Studies, University of London.

[2] Allen, R.G., Pereira, L.S., Raes, D., Smith, M., 1998. Crop evapotranspiration: guidelines for computing crop water requirements, FAO Irrigation and Drainage Paper 56. United Nations Food and Agriculture Organization, Rome.

[3] Cuenca, R.H., 1989. Irrigation System Design: An Engineering Approach. Prentice-Hall Inc., Englewood Cliffs, NJ, USA, 552 pp.

[4] FAO, 2009. CROPWAT 8.0 model, Food and Agriculture Organization, Rome, Italy. [online] www.fao.org/nr/water/infores_databases_cropwat.html. [Accessed on March 2012].

[5] Hoekstra, A.Y., Chapagain, A.K., Aldaya, M.M. and Mekonnen, M.M., 2009. Water footprint manual: State of the art 2009, Water Footprint Network, Enschede, the Netherlands.

[6] Loiseau, E. 2010. Environmental impacts evaluations methods of water use. Bibliotheque synthesis. AgroParisTechENGREF centre de Montpellier. 18p

[7] ONAGRI, 2010:

http://www.onagri.tn/STATISTIQUES/ENQUTES\%20STRU CTURES/ESEA\%202004-2005.htm\#_Toc125361774.

[Accessed on May 2012].

[8] Point Focal Tunisien du SEMIDE, (2002). http://www.semide.tn/english/contressource.htm Accessed on 20/07/2013

[9] Smith, M., 1993. CLIMWAT for CROPWAT, a climatic database for irrigation planning and management. FAO Irrigation and Drainage Paper 49, Rome, 113 pp.

[10] Velázquez, E., (2007).Water trade in Andalusia. Virtual water: An alternative way to manage water use. Ecological economics Vol. (63), (201-208). 